Олга М. СТОЈАНОВИЋ ${ }^{*}$ Ludwig-Maximilian-Universität München
Оригинални научни рад

Примљен: 25. 11. 2016. Прихваћен: 10. 02. 2017.

\title{
О ВИДСКОМ ПАРњАШТВУ ГЛАГОЛА ИЗ КОГНИТИВНЕ И КОМПАРАТИВНЕ ПЕРСПЕКТИВЕ
}

\begin{abstract}
У раду се наводе имплицитни индикатори асиметрије унутар видских парова у словенским језицима и у српском језику, који упућују на то да су чланови видског пара функционално и когнитивно неравноправни. У наставку се представља когнитивна аспектолошка теорија немачког слависте Фолкмара Лемана, по којој су аспекти хетерогено, степеновано организоване категорије са центром и периферијом. На крају се приказују резултати емпиријског истраживања на српском корпусу који потврђују основне постулате Леманове теорије.

Кључне речи: категорија аспекта, видски парови, когнитивна лингвистика, емпиријско истраживање, српско-немачка контрастивна лингвистика
\end{abstract}

\section{1. Увод: Индикатори асиметрије унутар видског пара}

Као теоријска основа аспектолошких проучавања у словенским језицима прихваћен је биполарни аспекатски систем свршеног и несвршеног вида, у оквиру којег се смешта и тумачи глаголска лексичка грађа. Притом се имплицитно полази од идеје две функционално симетричне и хомогене категорије, групе перфективних и групе имперфективних глагола, чији чланови граде видске парове уз мање или веће варијације у семантичким и деривационим релацијама. О питањима маркираности или примарности једног од два видска пола или асиметрије глаголских парњака говорило се углавном спорадично.

У нашој лингвистици на асиметрију унутар глаголског пара указивали су Ирена Грицкат и Иван Клајн, и то при прегледу лексикографског материјала у потрази за глаголима без видског парњака. Грицкат код истраживача

\footnotetext{
*olga.stojanovic@slavistik.uni-muenchen.de
} 
необичне лексике примећује тенденцију да „забележе пример са свршеним глаголом, сматрајући га носиоцем значења које се обелодањује”, а у лексикографији „сажимање дефиниције несвршеног глагола у поређењу са дефиницијом свршеног” (Грицкат 1985: 197-198). Иако је у њеном раду фокус на односима између префиксираних свршених и секундарно имперфектизованих несвршених глагола, што уз семантичку анализу може да објасни наведену неравнотежу, има и других индикатора асиметричног статуса парњака. Иван Клајн разматра разлику у пракси у обради видских парњака у лексикографским и граматичким публикацијама и не проналази консеквентан приступ том проблему. У неким публикацијама, као што је и Речник Матице српске, пракса упућивања са несвршених глагола на одговарајуће свршене омогућује да се закључи „да се свршени схвата као примаран или важнији од два вида, за шта нема стварне потврде” (Клајн 2011: 54). Са друге стране, неки други аутори су склони да несвршеним глаголима дају предност као немаркираним члановима аспекатске опозиције. У једном новијем когнитивно-лингвистичком истраживању са ученицима основних и средњих школа, емпиријски су истраживани прототипи асоцијативним анкетама, при чему је један од добијених резултата да ,у нултом контексту и код основаца и код средњошколаца убедљиво доминирају имперфективни глаголи као немаркирани чланови опозиције” (Вељковић Станковић 2013: 101). ${ }^{1}$

На сличне недоследности наишли смо и у немачко-српским речницима и у контрастивним немачко-српским граматикама и уџбеницима. Као егземпларан можемо представити одељак о реченичним обрасцима у немачком и српском језику из најновије Контрастивне српско-немачке граматике У. Енгела и С. Срдић. У прегледима реченичних образаца за фреквентне немачке глаголе као корелат је навођен углавном по један српски глагол, час перфективног, час имперфективног вида, а у ређим случајевима и оба пара или глагол са префиксом у загради, као што се види на следећим изабраним примерима:

$\begin{array}{ll}\text { anziehen } & \text { обући (Енгел/Срдић/Алановић 2012: 68) } \\ \text { begrüßen } & \text { поздравити (69) } \\ \text { bestellen } & \text { поручити (69) } \\ \text { bringen } & \text { донети (75) } \\ \text { geben } & \text { дати (74) } \\ \text { unterbrechen } & \text { прекинути (71) } \\ \text { riechen } & \text { (на)мирисати (71) } \\ \text { schreiben } & \text { (на)писати (71) } \\ \text { waschen } & \text { (о)прати (72) } \\ \text { ablehnen } & \text { одбити, одбацити (68) } \\ \text { gießen } & \text { залити, заливати (70) } \\ \text { ändern } & \text { мењати, променити (68) }\end{array}$

\footnotetext{
${ }^{1}$ Ауторка студије доминацију имперфективних глагола објашњава „свешћу о отворености акционалне структуре догађаја”: „примарно осећање времена” подразумева укљученост говорника у ситуацију што је могуће само код радњи несвршених глагола као процесу који је у току, док је „перфектив маркирани члан видске категорије, јер имплицира специфичну дистанцираност” (уп. Вељковић Станковић 2013: 93).
} 
Како се ради о прегледу реченичних образаца, разумљиво је да су аутори тражили лексичке корелате аналогне семантике и рекције, док вид није био експлицитно обележаван нити разматран. Исто тако, у многим оваквим случајевима семантика глаголске одреднице у немачком језику или структура српског видског пара не налаже обавезно појављивање целог видског пара. Али, има и много примера где се као српски корелат могао појавити видски пар, нпр. код geben - дати/давати, finden - наћи/налазити, а није. Поред тога, на први поглед нелогично је и да се код неких глагола ипак дају оба вида, при чему критеријум за такву обраду није експлициран, а у појединим случајевима је као корелат немачком глаголу дат један, а у примеру други српски глагол:

unterbrechen

Wir unterbrechen die

Sitzung (für zwanzig Minuten)

\section{прекинути}

Прекидамо седницу (на двадесет минута) (исто, 71, истицање О. С.)

Овакав приступ сугерише да је у погледу глаголског вида поступано спонтано и да су аутори тражили српски корелат који први семантички и по рекцији одговара немачком глаголу, тако да у овом прегледу можемо потражити индикаторе о постојању когнитивних, несвесних законитости у поступању са овом граматичком категоријом.

На први поглед чини се да у овој листи, кад је реч о аспекту, не постоји неко начело. Али, на други поглед, овај и слични прегледи глагола ипак откривају јасан принцип: по правилу су немачки глаголи са значењем епизодичности, пунктуалности, почетка или краја радње итд. описани српским перфективним, а они са акционалним значењем трајања, стања, понављања радње и слично - српским имперфективним глаголима, и то и у случајевима када постоји видски парњак потпуно истог значења ${ }^{2}$. Ови индикатори неравноправног статуса чланова једног видског пара могу се допунити и другима - на пример њиховом различитом фреквенцијом у употреби или различитим статусом у домаћим лексикографским публикацијама. У истраживањима усвајања језика код деце такође је примећено да се чланови видског пара у дечјем говору не појављују у исто време него сукцесивно, тако да је у најранијим стадијумима развоја језички израз такорећи моновидски, а видски парњаци се усвајају много касније (уп. Гагарина 2008).

Управо овакви индикатори навели су немачког слависту Фолкмара Лемана да се позабави категоријама перфективног и имперфективног вида из когнитивне перспективе и развије теорију о аспекту као хетерогено организованој категорији са центром и периферијом. У наставку ћу представити ову теорију и приказати резултате сопственог емпиријског истраживања на корпусу српских глагола, које је требало да испита Леманову тезу.

\footnotetext{
${ }^{2}$ У овом раду полазимо од постојања тзв. „чистих видских парова”, творених и префиксацијом и афиксацијом.
} 


\section{2. Когнитивна теорија аспекта Фолкмара Лемана}

У основи Леманове когнитивне теорије аспекта ${ }^{3}$ налази се хипотеза да аспекатске категорије у руском језику садрже функционално типичне и мање типичне елементе тако да не образују хомогене него хетерогене, степеноване категорије. Другим речима, категорија перфективних и категорија имперфективних глагола поседује одређен број типичних представника, по Леману алфа глагола, који чине центар своје категорије, и мање типичних, бета глагола, на периферији. У идеалном случају, видски глаголски пар састоји се од једног алфа и једног бета глагола, а алфа глаголи одликују се следећим дистинктивним особинама: они су чешће формално немаркирани, имају фреквентнију употребу и онтогенетски су примарни. Код видског пара решити / решавати свршени глагол, решити, представљао би алфа партнер а несвршени, решавати, бета.

Однос видских партнера међусобно и према ванјезичкој стварности Леман објашњава теоријом о развоју аспекатских категорија на почетку усвајања језика. За објашњење когнитивног утемељења категорија аспекта Леман преузима појмове из психолингвистике, у првом реду термин „психичког сада" (das Psychische Jetzt) неуролога Ернста Пепела (Пепел 1987), који по Леману одлучујуће детерминише развој језика и концепата епизодичности односно трајања у најранијим стадијумима усвајања језика.

Током перцепције акционалних радњи, у дечјем развоју језика настају примарни појмови којима се перципирана радња језички кодира. У случају глагола, одлучујуће је да ли се радња перципира као јединствен, епизодичан догађај или као вишефазни или статични акт. Као когнитивни шаблон за одређивање ове разлике Леману служи 'психичко сада' Ернста Пепела, који је експериментално показао да се вишефазни опажаји доживљавају као јединствена ситуација само у временском интервалу до око 3 секунде. Временски дужи опажаји остају когнитивно забележени као хетерогене, вишефазне или статичне ситуације. По Леману је овде зачетак формирања аспекатских категорија: ситуативни стимулуси деле се на епизодичне, који су опажени као целина у временском оквиру 'психичког сада' (устајање, затварање врата, улажење у собу и сл.), и на вишефазне, статичне или нединамичне ситуације (писање, спавање, ходање, веровање...). Као прве концептуализације ових опажаја настају тзв. примарни ситуациони појмови (primäre Situationsbegriffe):

- примарни појмови догађаја за ситуације у оквиру 'психичког сада'

- примарни процесуални појмови за ситуације које обухватају временски више интервала и састоје се из више фаза (ходање)

- примарни статични појмови за нединамичне ситуације (вољење, веровање)

\footnotetext{
${ }^{3}$ Теорија је представљена у Леман 1993 и Леман 2010, а као концептуална основа појављује се и у другим радовима овог аутора.
} 
- $\quad$ примарни резултативни појмови за опажање стања по завршетку извођења неке радње (нешто је сломљено, неко је ушао/изашао и сл.)

- примарни интенционални појмови за ситуације које се изражавају као намера, воља, морање, потреба идр.

Леман ове појмове схвата као концептуалне маске засноване на разликовању ситуација у раном опажању спољашњег света, и као такви они разликују основне ситуативне параметре: ситуативни облик (догађај, процес или статична ситуација), епизодичност, унутрашњу границу радње/теличност, трајање и, као онтогенетски последње, хронолошко ситуирање радње на временској скали. Примарни појмови се затим кодирају језичким формама: процесуални појмови презентском формом имперфективног глагола (сnавам, читам), резултативни појмови претериталном формом перфективног глагола ( ушао, пала), интенционални појмови инфинитивом или императивом (седи!), а статични појмови презентом имперфективног глагола (волим $)^{4}$. Примарни појмови носиоци су тако примарних функција, сачињених од различитих обележја ситуације, који се појављују у кластерима, односно у међусобно комплементарним скуповима обележја. Јединство форме (примарни појам) и одговарајућег кластера особина (примарни процесуални појам и прогесивни кластер) ће у даљем развоју бити разбијено тако што ће се функционална обележја из различитих кластера комбиновати међусобно и на тај начин категорије отворити за експанзију на разнолике ситуације које више не морају обавезно бити детерминисане когнитивним шаблоном 'психичког сада'. Тако ће, на пример, телична радња грађења куће, независно од њеног стварног трајања у времену, бити обележена као радња са унутрашњом границом и потпасти под категорију перфективног аспекта, која је примарно настала на основу опажаја временски кратких, пунктуалних радњи. У овом случају су обележја процесуалности и унутрашње границе комбинована на нов начин, тако да је категорија перфективности проширена новим лексемама са новом комбинацијом обележја. У процесу овог растакања примарних кластера функција долази и до развоја деиктичких темпоралних функција (садашњости, прошлости, будућности), тако да се акционална обележја и одговарајуће лексеме у комбинацији са темпоралним функцијама изнова профилишу. Претеритална форма (ушла), која је примарно обележавала статичан резултат обављене радње у тренутку говора односно опажања, сада може обележавати и динамичан, епизодичан догађај у прошлости. Касније профилисање аспекатских функција одвија се у реченичном и контекстуалном окружењу, уз учешће неколико функционалних операција. Као онтогенетски последњи корак у развоју Леман описује изградњу наративних темпоралних функција у приповедачком тексту, који је по својој природи одвојен од референцијалног оквира наратора и са редукованим деиктичким елементима.

У вези са идејом о типичним и нетипичним представницима видских категорија и функционалном или формалном симетричношћу вида, Леман

\footnotetext{
${ }^{4}$ Примери за пољски језик у Леман 1990, а за руски у Леман 1992.
} 
не посматра бинарни систем два аспекта у међусобном односу него предлаже степеновање унутар сваке аспекатске категорије, чиме је у Леман 1993 и започео обликовање своје когнитивистичке теорије. Испитујући корелацију између фреквентности глаголских лексема у употреби, њихових лексичких функција и формалне маркираности, он показује да су видски парњаци по правилу неравноправни по квантитативним мерилима, тј. да се један глагол из пара чини 'важнијим' од другог, и да је најчешће фреквентнији глагол и формално једноставнији.

Да би функционално објаснио ове феномене, Леман дели глаголе на оне који су онтогенетски настали перцепцијом ситуација из објективне стварности (алфа глаголи), и друге, који су настали рекатегоризацијом првих (бета глаголи). Примарни глаголи, који су тенденционално и фреквентнији, когнитивно привилегованији и најчешће формално немаркирани, чиниће центар своје видске категорије и фунгираће као основа за настанак секундарних, бета глагола, који чине периферију. Функционално-граматичка категоризација алфа глагола део је усвајања језика у његовом онтогенетском развоју, а сукцесивно му следи рекатегоризација у бета глаголе. У случају видских парњака, обе лексеме реферишу на исти ситуациони тип стварне радње, и у томе почива њихова заједничка лексичка функција. Оно што се мења је само акционално фокусирање ситуације, односно додатно фокусирање појединих обележја ситуације као што су епизодичност, процес, итеративност и сл. Рекатегоризација представља формалну и граматичку деривацију уз промену функционалних обележја лексеме, која на тај начин постаје секундарна утолико што је мотивисана не објективном ситуацијом него другом лексемом (алфа глаголом), а у том процесу и формално маркирана одговарајућим деривационим формантима (префиксима и инфиксима).

Следећи овај концепт глаголског вида, Леман долази до следеће дефиниције аспекта:

„1. Аспект се састоји из граматичке опозиције између израза чије функције се заснивају на обради директног или индиректног искуства из стварности и израза чије функције произлазе из формално изведене рекатегоризације.

2. Опозициони изрази имају неке заједничке функције - лексичке - а у неким функцијама се разликују - граматичким" (Леман 1993: 272).

Хипотезе о степенованости аспектских категорија Леман је проверавао испитивањем постојања корелације између алфа статуса, немаркираности и фреквентности на корпусу руских глагола, при чему је утврђена висока корелација између ових фактора. Анализирајући корелације лингвистичких и концептуалних (психолингвистичких) фактора, Леман показује на корпусу асоцијативног речника руског језика да постоји и упадљива корелација између когнитивно привилегованих, односно као асоцијација чешће навођених глагола и њиховог формалног облика, и наводи то као аргумент против традиционалне „поделе функција језичких израза на (формално оријентисан, логички предочен) лингвистички ниво и (интерференцијално оријентисан, психолошки предочен) концептуални ниво" (Леман 1993: 296). 
Даље аргументе за тезу о степенованости категорије вида донели су радови истраживача који су пре свега у различитим психолингвистичким и развојнопсихолошким истраживањима проналазили потврде за когнитивну привилегованост одређених глаголских лексема из глаголског видског пара. Истраживања са руским матерњим говорницима изван руског језичког простора донела су сличне резултате, као и огледи са децом као испитаницима. ${ }^{5}$ У истраживањима о усвајању језика код руских говорника Леманове идеје показале су се као корисне за тумачење неких до сада недовољно објашњених процеса развоја аспекатских категорија у најранијим стадијумима дечјег говора (упр. Анштат 2008).

\section{3. Теорија аспекта на српском корпусу}

Како је у постојећим истраживањима Леманова теорија била експериментално испитивана на корпусу руског и пољског језика, занимало нас је да ли је могуће проверити тезу о алфа и бета статусу глагола и на српским примерима. За формирање огледа искористили смо могућност да испитамо билингвалне говорнике српског и немачког језика и саставимо двојезични психолингвистички тест. Пошто смо хтели да проверимо тезу о когнитивној привилегованости одређених глагола видских парова, употребили смо модел асоцијативног теста са очекиваним реакцијама на одређене стимулусе. Као стимулусе одабрали смо 48 високо фреквентних немачких глагола у инфинитиву, без реченичног контекста, а задатак за учеснике огледа је био да се за сваки глагол напише његов српски превод, и то реч која испитанику прва падне на памет. Контролисан је билингвалан статус испитаника и време израде теста, а учесници нису знали позадину истраживања. Теоријска хипотеза ослања се на чињеницу да ће немачки глагол као стимулус бити у аспекатском смислу неутралан, тј. неодређен, тако да ће као реакцију изазвати онај видски партнер у српском који је когнитивно привилегован. При избору стимулуса водило се рачуна о томе да би се као реакција увек могле појавити две лексеме - видски пар без или скоро без семантичке разлике, дакле, чист аспекатски пар, као на пример код стимулуса öffnen, где су се могли појавити 'отворити' и 'отварати', или код bleiben - 'остајати' или 'остати' и сл. Исто тако, бирани су глаголи ниске полисемичности и са што мање могућих различитих лексема као потенцијалних српских корелата.

У 20 прегледаних, важећих тестова резултати су скоро потпуно идентични и поклапају се и са појавама примећеним у листи глагола из контрастивне граматике. Као реакција је у огромном броју случајева дата глаголска лексема у инфинитиву, а само на појединачним местима нека друга врста речи, углавном глаголска именица. Што се тиче наведених глагола, као реакција се у највећем броју случајева појављује само један глагол, а веома ретко видски

\footnotetext{
${ }^{5}$ Упр. Анштат 2008, Гагарина 2008, Класмајер 2015.
} 
пар. Према Лемановој теорији, испитаници су као асоцијацију навели когнитивно привилеговану и онтогенетски примарну лексему, тј. алфа глагол, који се појављује као прототипичан носилац значења за дату објективну ситуацију. Аспектуално неутралан стимулус из другог језика активирао је притом концепте релевантних карактеристика објективне ситуације (трајање, достизање унутрашње границе, епизодичност и пунктуалност), које су као реакцију у српском изазвале појаву оног аспекта за који су те карактеристике дистинктивни маркери.

На основу добијених резултата могуће је издвојити три групе глаголских лексема према категоријама аспекта, акционалог облика 'иманентне унутрашње границе' (теличности) и уједначености у добијеним одговорима испитаника. Једну групу чинили би ателични глаголи дуративног значења који су по правилу као реакцију изазвали српски несвршени глагол, као на пример:

\begin{tabular}{|c|c|c|c|}
\hline стимулус & реакција: асп. & постотак у \% & наведени глаголи \\
\hline schreiben & ипф. & 100 & писати \\
\hline singen & ипф. & 100 & певати \\
\hline lesen & ипф. & 100 & говорити, причати \\
\hline streiten & ипф. & 95 & свађати се \\
\hline
\end{tabular}

Слични резултати али са нижим постотком добијени су код транзитивних дуративних глагола са инхерентном границом, где је било и малобројних перфективних реакција:

\begin{tabular}{|c|c|c|c|c|}
\hline стимулус & реакција: асп. & $\begin{array}{c}\text { постотак } \\
\text { у\% }\end{array}$ & $\begin{array}{c}\text { наведени } \\
\text { глаголи }\end{array}$ & $\begin{array}{c}\text { алтернативни } \\
\text { одговори }\end{array}$ \\
\hline putzen & ипф. & 90 & $\begin{array}{c}\text { чистити, } \\
\text { рибати }\end{array}$ & очистити \\
\hline waschen & ипф. & 85 & прати & опрати \\
\hline bremsen & ипф. & 83 & кочити & закочити, укочити \\
\hline
\end{tabular}

Бројчано највећу групу чине глаголске одреднице са значењем теличности у ширем смислу, односно са акционалним видовима епизодичности, пунктуалности, промене стања, достизања инхерентне границе и слично. У убедљиво највећој мери они су асоцирани са српским свршеним глаголима: 


\begin{tabular}{|c|c|c|c|}
\hline стимулус & реакција: асп. & постотак у \% & наведени глаголи \\
\hline finden & пф. & 100 & наћи \\
\hline bestellen & п. & 100 & поручити \\
\hline retten & п. & 100 & спасити \\
\hline öffnen & п. & 95 & отворити \\
\hline verlieren & пф. & 95 & изгубити \\
\hline aufstehen & п. & 100 & устати, дигнути се \\
\hline schenken & пф. & 95 & поклонити, даровати \\
\hline
\end{tabular}

Овако уједначени резултати у добијеним одговорима примећују се код отприлике две трећине стимулуса. Нешто мање уједначене су реакције код десетак глаголских одредница, где је постотак појављивања исте, очекиване реакције, испод 80\%. Исто тако, код ових глагола појављивали су се појединачно и одговори где су наведена оба глаголска вида. То се десило, на пример, код следећих стимулуса:

\begin{tabular}{|c|c|c|c|c|c|}
\hline стимулус & $\begin{array}{c}\text { доминантна } \\
\text { реакција и } \\
\text { постотак }\end{array}$ & $\begin{array}{c}\text { наведен } \\
\text { глагол }\end{array}$ & $\begin{array}{c}\text { алтернативна } \\
\text { реакција и } \\
\text { постотак }\end{array}$ & $\begin{array}{c}\text { наведен } \\
\text { глагол }\end{array}$ & $\begin{array}{c}\text { остале } \\
\text { реакције }\end{array}$ \\
\hline übersetzen & п. $55 \%$ & превести & ипф. $35 \%$ & преводити & $\begin{array}{c}\text { пф. + } \\
\text { ипф. } 10 \%\end{array}$ \\
\hline wiederholen & пф. $78 \%$ & поновити & ипф. $22 \%$ & понављати & - \\
\hline fallen & пф. $70 \%$ & пасти & ипф. $20 \%$ & падати & $\begin{array}{c}\text { пф. + } \\
\text { ипф. } 10 \%\end{array}$ \\
\hline gefallen & ипф. $63 \%$ & $\begin{array}{c}\text { свиђати, } \\
\text { допадати }\end{array}$ & пф. $37 \%$ & $\begin{array}{c}\text { свидети, } \\
\text { допасти }\end{array}$ & - \\
\hline sich erinnern & пф. $65 \%$ & сетити се & ипф. $35 \%$ & сећати се & - \\
\hline
\end{tabular}

Овакви глаголи би могли одговарати Лемановој касније уведеној категорији дифузних лексема који алфа или бета статус стичу тек у конкретном контексту, у зависности од фокусирања радње, темпоралних одредница, тема-рема-односа и сл. Они садрже компоненте и процесуалности али и достизања инхерентне границе, при чему је у зависности од контекстуалних фактора могућа профилација једног или другог аспекта. Претпоставка је да би додатни тестови са овим глаголима у реченичном или другачијем асоцијативном контексту у овом случају дали прецизније резултате.

Наведени резултати огледа поткрепљују у целини Леманову теорију о когнитивној и функционалној асиметрији видских парова и на српским примерима и потврђују примећене феномене из лексикографске праксе у 
обради глаголских јединица. Леманова теорија и сама је овде схваћена као концептуално отворена теорија која почива на више поставки које су и даље предмет дискусије, као на пример само постојање чистих аспекатских парова или аспектуалне деривације морфолошким средствима. Као когнитивна теорија, она покушава да превазиђе методолошке и терминолошке слабости постојећих когнитивистичких истраживања категорије аспекта, као што су концепти менталних модела (Дарст-Андерсен 1992) или Дикијевих аксиома (Дики 2000), а са теоријом о типичним и нетипичним представницима видских категорија и степенованости аспекта нуди и концептуална решења за нека отворена питања из области видског парњаштва, аспекатске симетрије и онтогенетског језичког развоја.

\section{ЛИТЕРАТУРА}

Анштат 2008: T. Anstatt, „Lexikalisierung des Aspekts? Alpha- und Beta-Verben bei bilingualen russisch-deutschen Kindern", y: Aspekte, Kategorien und Kontakte slavischer Sprachen (ред. B. Brehmer et al.), Hamburg: Kovač, $13-28$.

Вељковић Станковић 2013: Д. Вељковић Станковић, „Могућности примене когнитивног приступа у настави српског језика (на примеру обраде граматичке категорије глаголског вида)", Научни састанак слависта $y$ Вукове дане, 42/3, 85-113.

Гагарина 2008: N. Gagarina, „Gestufte Nature of Aspectual Pairs”, y: Aspekte, Kategorien und Kontakte slavischer Sprachen (ред. В. Brehmer et al.), Hamburg: Kovač, 161-172.

Грицкат 1985: И. Грицкат, „Одлике глаголског видског парњаштва као семантички индикатори", Зборник Матище српске за филологију и лингвистику, XXVII-XXVIII, 197-203.

Дарст-Андерсен 1992: P. Durst-Andersen, Mental Grammar. Russian Aspect and Related Issues, Ohio: Columbus.

Дики 2000: S. M. Dickey, Parameters of Slavic Aspect: a Cognitive Approach, Stanford: CSLI Publications.

Енгел/Срдић/Алановић 2012: U. Engel, S. Srdić, M. Alanović, Deutsch-serbische kontrastive Grammatik. Teil I: Der Satz, München: Otto Sagner.

Клајн 2011: И. Клајн, „Видски парови у лексикографској перспективи”, Глас CAHУ CDXVIII, Одељење језика и књижевности, књ. 27, 51-83.

Класмајер 2015: C. Clasmaier, Die mentale Repräsentation von Aspektpartnerschaften russischer Verben, Leipzig: Biblion Media.

Леман 1990: V. Lehmann, „Zur ontogenetischen und diachronen Entwicklung grammatischer Kategorien des Polnischen”, y: Slavistische Linguistik 1989 (ред. W. Breu), München: Sagner, 167-188. 
Леман 1992: V. Lehmann, „Terminativität als Sonderfunktion des imperfektiven Aspekts", у: Т. Reuther (ред.), Slavistische Linguistik 1991, München: Sagner, 227-240.

Леман 1993: V. Lehmann, „Die russischen Aspekte als gestufte Kategorien”, Welt der Slaven, 38/2, 265-297.

Леман 2010: V. Lehmann, „Der slavische Aspekt im Licht der kognitiven Linguistik", Die slavischen Sprachen im Licht der kognitiven Linguistik / Cлавянские языки в когнитивном аспекте (ред. T. Anstatt et al.), Wiesbaden: Harrassowitz, 77-99.

Пепел 1987: E. Pöppel, Grenzen des Bewußtseins. Über Wirklichkeit und Welterfahrung, München: dtv.

Olga Stojanović

\section{ZU DEN VERBALEN ASPEKTPAAREN AUS DER KOGNITIVEN UND KOMPARATIVEN PERSPEKTIVE}

\section{Zusammenfassung}

Aufgrund einiger Indikatoren für den asymmetrischen Status der verbalen Aspektpaare in den slavischen und in der serbischen Sprache wird die Annahme von einem funktionalen und kognitiven Gefälle zwischen den Gliedern des Aspektpaares diskutiert. Eine theoretische Antwort auf diese Frage bietet die kognitive Aspekttheorie des deutschen Slavisten Volkmar Lehmann, die in Grundzügen vorgestellt wird. Die Grundhypothese dieser Theorie wird am Korpus der frequenten serbischen Verben in einem psycholingistischen Experiment mit biligualen Teilnehmern überprüft, deren Ergebnisse hier vorgestellt werden.

Кључне речи: Verbalaspekt, Aspektpaare, kognitive Linguistik, empirische Forschung, deutschserbische kontrastive Linguistik. 